\title{
Plant growth-promoting rhizobacteria able to improve NPK availability: selection, identification and effects on tomato growth
}

\author{
Altagracia Reyes-Castillo ${ }^{1,3}$, Macarena Gerding ${ }^{2 *}$, Pía Oyarzúa ${ }^{2}$, Erick Zagal ${ }^{2}$, Javiera Gerding ${ }^{4}$, \\ and Susana Fischer ${ }^{2}$ \\ 'Instituto Nacional de Investigaciones Forestales, Agrícolas y Pecuarias (INIFAP), Campo Experimental Tecomán, \\ Colima, CP. 28100 México. \\ ${ }^{2}$ Universidad de Concepción, Facultad de Agronomía, Av. Vicente Méndez 595, Chillán, Chile. \\ "Corresponding author (mgerding@udec.cl). \\ ${ }^{3}$ Universidad de Concepción, Facultad de Agronomía, Programa de Doctorado en Ciencias de la Agronomía, Av. Vicente Méndez 595, \\ Chillán, Chile. \\ ${ }^{4}$ Centro de Estudios Mineralógicos, Geoatacama, Río Lauca 3194, Coquimbo, Chile.
}

Received: 14 February 2019; Accepted: 2 May 2019; doi:10.4067/S0718-58392019000300473

\begin{abstract}
Nitrogen, $\mathrm{P}$ and $\mathrm{K}$ are essential macronutrients that are not readily available to plants. Rhizobacteria are able to convert these unavailable forms for subsequent uptake by the plant, diverse species have been characterized as $\mathrm{N}_{2}$ fixers, $\mathrm{P}$ solubilizers and capable to solubilize mineral $\mathrm{K}$ from unavailable forms. The objective of this study was to select rhizobacteria capable of improving NPK availability and promoting tomato (Solanum lycopersicum L.) growth. Fifteen strains were studied. Four strains were selected for their capacity to fix $\mathrm{N}_{2}$, three for their ability to solubilize $\mathrm{P}$, and six for their capacity to solubilize biotite and K-feldspar, isolated from tomato, lentil, chili pepper, faba bean and lettuce crops in Andisol and Alfisol soils. Through 16SrRNA sequencing, selected strains were identified as Pseudomonas gessardi, $P$. koreensis, P. brassicacearum, P. marginalis, Acinetobacter calcoaceticus and Rahnella aquatica. Phosphorus solubilizing strains did not show a positive effect on plant growth or an increase in available soil $\mathrm{P}$. The $\mathrm{N}_{2}$ fixing bacteria Tmt-16 strain increased root growth in 23.57\%; maintained the highest $\mathrm{N}$ content in plant tissue, $2.60 \%$, higher amount of $\mathrm{N}$ available in the soil, $2.95 \mathrm{mg} \mathrm{kg}^{-1}$, and a higher content of $\mathrm{N}^{-N_{4}}{ }^{+} 1.95 \mathrm{mg} \mathrm{kg}^{-1}$. The $\mathrm{K}$ solubilizing strains Ls-C21, Ltj-62 and LsC-58 reached 17.0 to $19.0 \mathrm{mg} \mathrm{kg}^{-1}$ available $\mathrm{K}$ and 0.04 to $0.05 \mathrm{mg} \mathrm{kg}^{-1}$ exchangeable $\mathrm{K}$ ( $\mathrm{p} \leq 0.05$.). These four endemic rhizobacteria can be potentially used as biofertilizers, allowing a reduction in the use of chemical fertilizers and a more sustainable production of tomatoes.
\end{abstract}

Key words: Acinetobacter, $\mathrm{N}_{2}$ fixation, phosphorus and potassium solubilization, Pseudomonas, Rahnella, Solanum lycopersicum.

\section{INTRODUCTION}

Nitrogen, $\mathrm{P}$ and $\mathrm{K}$ are essential macronutrients for plant growth and crop yield. However, they are not readily available to plants (Meena et al., 2014). The largest reservoir of $\mathrm{N}$ is found in the form of atmospheric $\mathrm{N}(78 \%)$, in a form biologically unavailable to plants (Hartono et al., 2016). Phosphorous in soil is present as $\mathrm{P}$ in solution, insoluble organic $\mathrm{P}$ and insoluble inorganic $\mathrm{P}$, soils are often high in insoluble mineral phosphates but deficient in soluble orthophosphate, which is essential for the growth of most plants (Hariprasad and Niranjana, 2009). The concentration of soluble K in soil is usually very low (1\% to $2 \%$ ) since $\mathrm{K}$ is mainly present as insoluble rocks, silicate minerals and other deposits, although 
it is not always available to plants (Parmar and Sindhu, 2013). Rhizobacteria are able to convert unavailable forms of nutrients into available ones for subsequent uptake by the plant (Meena et al., 2014).

Plant growth-promoting rhizobacteria (PGPR) are soil bacteria that are able to colonize rhizosphere and to enhance plant growth by means of a wide variety of mechanisms. Diverse species PGPR have been characterized as N fixers, $\mathrm{P}$ solubilizers and capable to solubilize mineral $\mathrm{K}$ from unavailable forms. $\mathrm{N}_{2}$ fixation occurs when molecular $\mathrm{N}\left(\mathrm{N}_{2}\right)$ is converted into ammonia $\left(\mathrm{NH}_{3}{ }^{-}\right)$by the enzyme complex nitrogenase, which consists of two metalloproteins, the molybdenum-iron protein (Protein 1) and the iron-protein (Protein 2). Nitrogenase requires the collaboration of two other proteins: ferrodoxin and avodoxin, which act as electron donors and natural reducers of nitrogenase. The electrons are transported to the nitrogenase by ferrodoxin and reach the iron-protein. This activates the Mo-Fe-protein and the reduction of $\mathrm{N}_{2}$ occurs, being then fixed as an amino compound (Hoffman et al., 2014). Solubilization of inorganic P occurs by secretion of organic and inorganic acids, such as citric, lactic, succinic and gluconic acids. Hydroxyl and carboxyl groups of acids chelate cations $\left(\mathrm{Ca}^{2+}\right)$ and lower the $\mathrm{pH}$ by releasing the phosphates (Behera et al., 2014). Potassium-solubilizing bacteria (KSB) can produce several types of organic acids; succinic, citric, gluconic, $\alpha$-ketogluconic and oxalic, and inorganic; acetate, citrate, oxalate that when released to the rhizosphere cause the fixed $\mathrm{K}$ of the minerals to be released and dissolved by processes of acidolysis, chelation and complexolysis. The solubilization of $\mathrm{K}$ varies with the nature of the minerals (motmorillonite, kaolinite, K-feldspar, muscovite, biotite, illite, orthoclases) that contain $\mathrm{K}$ and aerobic conditions (Meena et al., 2015).

Of the large number rhizobacteria, the following genera have shown potential as biofertilizers or growth promoters: Azospirillum, Azotobacter, Pseudomonas, Acinetobacter Beijerinckia, Derxia, Herbaspirillum, Burkholderia, Gluconacetobacter, Enterobacter, Bacillus, Rahnella, Alcaligenes, Klebsiella, Lysobacter and Paenibacillus. The use of PGPR has proven to be an environmentally sound way of increasing crop yields by facilitating plant growth. It can also reduce production costs and the environmental impact associated with chemical fertilization (Majeed et al., 2018).

Several PGPR have been isolated from different soils and crops in Central Chile and have shown that they can promote root and aerial growth, and increase nodule formation in legumes (Gerding et al., 2017; Sepúlveda-Caamaño et al., 2018; Cedeño-García et al., 2018). The aim of this study was to select rhizobacteria capable of improving NPK availability and promoting tomato growth.

\section{MATERIALS AND METHODS}

\section{Selection of rhizobacteria for $\mathrm{N}_{2}$ fixation, and solubilization of $\mathrm{P}$ and $\mathrm{K}$}

Fifteen bacterial isolates from the Microorganism Collection of the Faculty of Agronomy, Universidad de Concepción, Chillán, Chile, were studied. These isolates had been formerly collected from the rhizosphere of nine major agricultural crops in Chile, grown in different soils of the Maule, Ñuble and Biobío Regions (Table 1). The isolates were reactivated in standard nutrient agar.

The bacteria were evaluated under laboratory conditions for (1) $\mathrm{N}_{2}$ fixation, (2) P inorganic solubilization, and (3) K solubilization of minerals. Using the specific culture media Burk's, N-free medium (Hartono et al., 2016), Pikovskaya (PVK) (Hariprasad and Niranjana, 2009) and modified Aleksandrov medium (MAMs), waste mica was used biotite (11\% K) and K-feldspar (14\% K) (Meena et al., 2015), respectively.

Capacity of the isolates to fix $\mathbf{N}_{2}$ and solubilize $\mathbf{P}$ and $\mathrm{K}$. The screenings were carried out with three replicates for each of the isolates. Petri dishes with Burk's and PVK were incubated at $25^{\circ} \mathrm{C}$ for $72 \mathrm{~h}$, while MAMs was incubated at $28 \pm 1{ }^{\circ} \mathrm{C}$ for $7 \mathrm{~d}$. The ability of the isolates to fix $\mathrm{N}_{2}$ and solubilize $\mathrm{P}$ and $\mathrm{K}$ was evaluated as follows: $\mathrm{N}_{2}$ fixation was assessed by measuring the growth of the bacterial colony in N-free medium (Burk's). A numerical scale for growth in Burk's culture medium (GBCM) was used, where 3 was considered abundant growth; 2, good growth; 1, moderate growth; and 0 (zero), no visible growth. To evaluate $\mathrm{P}$ and $\mathrm{K}$ solubilization in PVK and MAMs, the diameter $(\mathrm{mm})$ of the solubilization halo (translucent zone produced around each colony) was measured using a digital vernier (Hariprasad and Niranjana, 2009; Meena et al., 2015). Microphotographs of feldspar-K solubilization in MAMs media were taken from plates with and without bacterial inoculum. The microphotographs were taken at the Center for Mineralogical Studies CEM Geoatacama, with a scanning electron microscope (VEGA3, TESCAN, Kohoutovice, Czech Republic). 
Table 1. Host plant, place of collection and production of NPK of the rhizobacteria.

\begin{tabular}{|c|c|c|c|c|c|c|c|c|c|c|}
\hline \multirow[b]{2}{*}{ Soil type } & \multirow[b]{2}{*}{ Geographic origin } & \multirow[b]{2}{*}{ Host plant } & \multirow{2}{*}{$\begin{array}{l}\text { Location in } \\
\text { the root }\end{array}$} & \multirow[b]{2}{*}{ Strain } & \multicolumn{2}{|c|}{$\begin{array}{c}\mathrm{N}_{2} \\
\text { Fixation } \\
\end{array}$} & \multicolumn{2}{|c|}{$\begin{array}{c}\mathrm{P} \\
\text { Solubilization } \\
\end{array}$} & \multicolumn{2}{|c|}{$\begin{array}{c}\mathrm{K} \\
\text { Solubilization } \\
\end{array}$} \\
\hline & & & & & GBC & $\mathrm{NH}_{4}^{+}$ & PSH & $\mathrm{PO}_{4}$ & $\mathrm{KSH}$ & $\mathrm{K}$ \\
\hline & & & & & & $m g L^{-1}$ & $\mathrm{~mm}$ & $\mathrm{mg} \mathrm{L}^{-1}$ & $\mathrm{~mm}$ & $\mathrm{mg} \mathrm{L}^{-1}$ \\
\hline \multirow[t]{11}{*}{ Andisol } & $36^{\circ} 37^{\prime} 21^{\prime \prime} \mathrm{S}, 71^{\circ} 51^{\prime} 53^{\prime \prime} \mathrm{W}$ & Capsicum аппиит $\mathrm{L}$. & Exorhizosphere & $\mathrm{Aj}-19 \mathrm{~b}$ & 3 & 1.4 & 5.1 & 109.2 & 0.0 & 24.0 \\
\hline & & Lens culinaris Medik. & Endorhizosphere & Ltj-62 & 2 & 0.2 & 5.4 & 120.5 & 3.8 & 29.0 \\
\hline & & Apium graveolens $\mathrm{L}$. & Exorhizosphere & Ap-3bF & 3 & 0.1 & 3.4 & 106.7 & 1.1 & 15.0 \\
\hline & & & Exorhizosphere & Ap-77a & 2 & 0.1 & 0.0 & 160.4 & 5.1 & 0.0 \\
\hline & & Vicia faba $\mathrm{L}$. & Endorhizosphere & $\mathrm{Hb}-142$ & 3 & 0.7 & 3.8 & 225.1 & 2.7 & 0.0 \\
\hline & & Solanum lycopersicum L. & Endorhizosphere & Tmt1-107 & 3 & 0.6 & 4.1 & 308.6 & 5.6 & 0.0 \\
\hline & $36^{\circ} 37^{\prime} 9^{\prime \prime} \mathrm{S}, 71^{\circ} 49^{\prime} 43^{\prime \prime} \mathrm{W}$ & Lactuca sativa var. capitata $\mathrm{L}$. & Exorhizosphere & Ls-C54 & 3 & 0.0 & 1.2 & 155.0 & 4.3 & 37.0 \\
\hline & $36^{\circ} 37^{\prime} 24^{\prime \prime} \mathrm{S}, 71^{\circ} 52^{\prime} 59^{\prime \prime} \mathrm{W}$ & & Endorhizosphere & Ls-C21 & 1 & 0.0 & 6.1 & 144.7 & 5.4 & 30.0 \\
\hline & $36^{\circ} 38^{\prime} 32^{\prime \prime} \mathrm{S}, 71^{\circ} 51^{\prime} 13^{\prime \prime} \mathrm{W}$ & & Endorhizosphere & Ls-C58 & 1 & 0.1 & 5.5 & 241.2 & 3.2 & 25.0 \\
\hline & $36^{\circ} 40^{\prime} 24^{\prime \prime} \mathrm{S}, 71^{\circ} 46^{\prime} 48^{\prime \prime} \mathrm{W}$ & Triticum aestivum $\mathrm{L}$. & Exorhizosphere & $\mathrm{T}-35 \mathrm{~b}$ & 3 & 0.1 & 1.9 & 133.5 & 3.8 & 20.0 \\
\hline & & & Rhizoplane & $\mathrm{T}-06$ & 3 & 0.2 & 0.0 & 126.4 & 5.4 & 12.0 \\
\hline \multirow[t]{3}{*}{ Ultisol } & $36^{\circ} 45.78^{\prime} \mathrm{S}, 72^{\circ} 04.8^{\prime} \mathrm{W}$ & S. lycopersicum & Exorhizosphere & Tmt-22 & 2 & 0.1 & 0.9 & 181.9 & 4.8 & 18.0 \\
\hline & & & Exorhizosphere & Tmt-16 & 1 & 1.7 & 5.5 & 84.4 & 1.5 & 5.0 \\
\hline & & & Exorhizosphere & Tmt-32 & 2 & 0.0 & 7.5 & 144.4 & 4.6 & 26.0 \\
\hline Alfisol & $35^{\circ} 57^{\prime} 20^{\prime \prime} \mathrm{S}, 72^{\circ} 17^{\prime} 9^{\prime \prime} \mathrm{W}$ & Medicago sativa $\mathrm{L}$. & Exorhizosphere & GE-11 & 3 & 0.3 & 1.0 & 165.8 & 3.6 & 0.0 \\
\hline
\end{tabular}

GBC: Growth in Burk's culture medium, 3 = abundant, 2 = good, 1 = moderate. PSH: Solubilization halo in Pikovskaya medium (PVK). KSH: Solubilization halo in modified Aleksandrov medium (MAMs).

Determination of NPK availability in solution. Burk's, PVK and MAMs liquid media were used to quantify the amount of fixed $\mathrm{N}$ and solubilized $\mathrm{P}$ and $\mathrm{K}$ by the bacterial strains selected. Liquid media were inoculated with each isolate and incubated in a rotary shaker $(150 \mathrm{rpm})$ at $25^{\circ} \mathrm{C}$ for $3 \mathrm{~d}$ for Burk's and PVK, and MAMs at $28 \pm 1{ }^{\circ} \mathrm{C}$ for $7 \mathrm{~d}$.

For each evaluation, $20 \mathrm{~mL}$ of bacterial suspension prepared with $100 \mu \mathrm{L}$ of bacterial culture (optical density (OD) 600 $\mathrm{nm}=1.0)$ suspended in $0.89 \% \mathrm{NaCl}(\mathrm{w} / \mathrm{v})$ were placed in $50 \mathrm{~mL}$ sterile falcon tubes. After incubation, the samples were centrifuged (Centrifuge 5804 R, Eppendorf, New York, USA) for $10 \mathrm{~min}$ at $11000 \mathrm{rpm}$; the supernatant was removed with a syringe with a sterile $0.45-\mu$ filter and placed in $16 \mathrm{~mL}$ sterile test tubes. Each filtered sample was used to determine $\mathrm{NH}_{4}{ }^{+}$, phosphate $\left(\mathrm{PO}_{4}\right)$ and $\mathrm{K}$ in solution.

The production of $\mathrm{N}^{-\mathrm{NH}_{4}}{ }^{+}\left(\mathrm{mg} \mathrm{L}^{-1}\right)$ by the selected isolates was assessed by direct Nesslerization (Vyas et al., 2010). For each sample, a volume of $2 \mathrm{~mL}$ of filtrate was taken. Then $2 \mathrm{~mL}$ Nessler reagent and $3 \mathrm{~mL} \mathrm{NaOH}(3 \mathrm{M})$ were added, vortexed and allowed to stand for 20 min before reading in the spectrophotometer (Optizen POP-Bio, Mecasys, Daejeon, Korea) at $490 \mathrm{~nm}$. The calibration curve was constructed with $\mathrm{N}^{-N_{4}}{ }_{4}^{+}$at $0,2,5,10,20$ and $30 \mathrm{mg} \mathrm{L}^{-1}$.

The solubilization of $\mathrm{P}_{-} \mathrm{PO}_{4}\left(\mathrm{mg} \mathrm{L}^{-1}\right)$ was assessed by colorimetry with the molybdenum blue method using $\mathrm{C}_{6} \mathrm{H}_{8} \mathrm{O}$ as reductant, with modifications (Behera et al., 2014). Samples of the filtrate were diluted 10 times. Volumes of $2 \mathrm{~mL}$ of the diluted sample were placed in $100-\mathrm{mL}$ flasks. Then $43 \mathrm{~mL}$ distilled water and $5 \mathrm{~mL}$ reagent were added to determine phosphate. The mixture was homogenized in an orbital stirrer (Super-Mixer, Lab-Line Instruments, Melrose Park, Illinois, USA) for $5 \mathrm{~s}$ and allowed to stand for $30 \mathrm{~min}$ to observe color changes to azure blue. The readings of the samples were performed on a spectrophotometer (UVE 054108, Helios Epsilon, Thermo Scientific, Waltham, Massachusetts, USA) at $720 \mathrm{~nm}$. The calibration curve was made with a phosphate standard solution at $1000 \mathrm{mg} \mathrm{P}-\mathrm{PO}_{4} \mathrm{~L}^{-1}$, at concentrations of

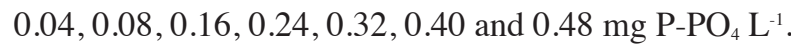

The solubilization of $\mathrm{K}_{\left(\mathrm{mg} \mathrm{L}^{-1}\right)}$ was determined by atomic emission spectrometry of air-acetylene flame by direct aspiration (Zhang and Kong, 2014). The readings of the samples were performed at a wavelength of 766.5 $\mathrm{nm}$. The calibration curve was performed with a standard solution of $1000 \mathrm{mg} \mathrm{L}^{-1}$ in the following concentrations $0.0,2.5$ and $5.0 \mathrm{mg} \mathrm{L}^{-1}$.

\section{Identification of selected bacterial isolates}

Cells were prepared for polymerase chain reaction (PCR), by suspending $100 \mu \mathrm{L}$ of bacterial culture in $900 \mu \mathrm{L}$ nuclease-free water and centrifuging at $5000 \mathrm{~g}$ for $5 \mathrm{~min}$. The supernatant was removed, and the cell pellet was 
resuspended in $1 \mathrm{~mL}$ nuclease-free water. This procedure was repeated twice and finally the cell concentration was standardized at an OD $600 \mathrm{~nm}=0.4$ (CE 1020, Cesil Instruments, Cambridge, UK). Finally, the samples were subjected to a temperature shock at $65{ }^{\circ} \mathrm{C}$ for $5 \mathrm{~min}$ and then at $-20^{\circ} \mathrm{C}$ for $5 \min$ (Guiñazú et al., 2013).

The 16S rRNA partial gene was amplified through PCR using the universal primers 27F (5'-AGAGTTTGATCATGGCTCAG-3') and 1492R (5'-GGTTACCTTGTTACGACTT-3'). The PCR reaction mix consisted of $2 \mu \mathrm{L}$ of cell suspension, $2 \mathrm{U}$ Taq DNA polymerase (GoTaq, Promega, Madison, Wisconsin, USA), $0.5 \mu \mathrm{M}$ of each primer, $1.5 \mathrm{mM} \mathrm{MgCl}_{2}, 1 \mathrm{X}$ GoTaq buffer solution, $0.2 \mathrm{mM}$ dNTPs and ultrapure water Hyclone (Thermo Scientific) for a final volume of $40 \mu \mathrm{L}$. The PCR conditions were the following: one initial denaturation step at $95{ }^{\circ} \mathrm{C}$ for $5 \mathrm{~min}$, followed by 30 cycles of denaturation at $94^{\circ} \mathrm{C}$ for $30 \mathrm{~s}, 55^{\circ} \mathrm{C}$ for $30 \mathrm{~s}$ and $72{ }^{\circ} \mathrm{C}$ for $90 \mathrm{~s}$, and a final extension at $72{ }^{\circ} \mathrm{C}$ for $7 \mathrm{~min}$. The amplification of the gene was verified through electrophoresis in agarose gel $1 \%(\mathrm{w} / \mathrm{v})$, stained with GelRed (Biotium, Hayward, California, USA) at $90 \mathrm{~V}$ for $45 \mathrm{~min}$ (Sepúlveda-Caamaño et al., 2018).

The PCR products were purified and sequenced at Macrogen Inc. (Seoul, Korea; http://dna.macrogen.com/eng). The chromatograms obtained were analyzed and edited in the GeneTool Lite 1.0 (2000) software. The phylogenetic tree was constructed using the Neighbor-Joining algorithm using MEGA 7 software (Tamura et al., 2004). Type strains sequences were obtained from GenBank of the National Center for Biotechnology Information (NCBI; https://www.ncbi.nlm.nih.gov).

\section{Endophytic capacity of selected bacterial isolates}

Fragments $3 \mathrm{~cm}$ long were taken from the distal ends of the roots, stem and leaves of the inoculated plants. Then these sections were washed in distilled water and disinfected superficially in 70\% ethanol for $2 \mathrm{~min}$, followed by immersion in $1 \%$ hypochlorite for $30 \mathrm{~s}$, and four washes in sterile distilled water. Subsequently, the fragments were cut into $1 \mathrm{~cm}$ pieces and cultured in standard nutrient agar plates, incubated for $48 \mathrm{~h}$ at $25^{\circ} \mathrm{C}$ (Parsa et al., 2013). The bacterial colonies developed from the ends of the cuts were re-isolated on standard nutrient agar and subject to the same growth conditions mentioned above. Each treatment was established in triplicate for molecular analysis.

The identity of the isolates obtained was assessed at the strain level by molecular fingerprinting using the primer BOX A1R (5'-CTA CAA CGG GCT GAC GGC GAC G-3') according to the methodology used by Guiñazú et al. (2013). The PCR reaction mix contained $5.0 \mu \mathrm{L}$ of cell template, $0.3 \mu \mathrm{L}$ Gotaq polymerase (Promega) $\left(5 \mathrm{U}_{\mu \mathrm{L}^{-1}}\right), 5.0 \mu \mathrm{L}$ A1R primer $(10 \mu \mathrm{M}) 0.5 \mu \mathrm{L}$ dNTPs $(10 \mathrm{mM}), 5.0 \mu \mathrm{L}$ Gotaq buffer $(5 \times)$ solution, $1.5 \mu \mathrm{L} \mathrm{MgCl}_{2}(25 \mathrm{mM})$ and $7.7 \mu \mathrm{L}$ ultrapure water, making a total of $25 \mu \mathrm{L}$. The PCR conditions were: $95^{\circ} \mathrm{C}$ for $7 \mathrm{~min}$; then 35 cycles at $94{ }^{\circ} \mathrm{C}$ for $1 \mathrm{~min} ; 52^{\circ} \mathrm{C}$ for 1 min and $72{ }^{\circ} \mathrm{C}$ for $8 \mathrm{~min}$; and finally, $72{ }^{\circ} \mathrm{C}$ for $16 \mathrm{~min}$ with amendments in the time of PCR runs. The PCR products were analyzed by electrophoresis in $2 \%(\mathrm{w} / \mathrm{v})$ agarose gels with $2.5 \mathrm{~mL}^{-1} \mu \mathrm{L}$ Gel Red $(10000 \times$ in DMSO, Biotium) in a $1 \times$ TAE buffer solution (40 mM Tris- acetate, $1 \mathrm{mM}$ EDTA, $\mathrm{pH} 8.0$ ) at $50 \mathrm{~V}$ for $3 \mathrm{~h}$. Bands were visualized in a UV transilluminator.

\section{Effects of the selected bacterial isolates in plant and soil}

The capacity of bacteria to promote plant growth in tomato 'Cal Ace' was evaluated. Plants were grown in speedlings using soil of the following characteristics as a substrate: $7.0 \mathrm{mg} \mathrm{kg}^{-1}$ available $\mathrm{N}$ (nitrates N-NO $3.90 \mathrm{mg} \mathrm{kg}^{-1}$ and ammonium $\left.\mathrm{N}-\mathrm{NH}_{4}{ }^{+} 2.10 \mathrm{mg} \mathrm{kg}^{-1}\right), 19.20 \mathrm{mg} \mathrm{kg}^{-1}$ available $\mathrm{P}, 40.90 \mathrm{mg} \mathrm{kg}^{-1}$ available $\mathrm{K}, 5.66 \mathrm{pH}$ in water and $4.18 \%$ organic matter. The soil was classified as Isotic, mesic Dystric Xeropsamments belonging to the Arenales series.

Three experiments were carried out, one for each type of selected bacteria; $\mathrm{N}_{2}$ fixing bacteria (3 NFB strains +1 negative control without inoculation), P solubilizers (4 PSB strains+ 1 negative control) and K solubilizers (5 KSB strains + 1 negative control). A completely randomized design was used with three replicates. Each experimental unit consisted of 27 plants.

The experiments were carried out in a phytotron with high-pressure sodium steam lamps (400 W Gro-lux, Osram Sylvania, Danvers, Massachussetts, USA) providing a minimum photosynthetic photon flux density (PPFD) of 400$500 \mathrm{~mol} \mathrm{~m}^{2} \mathrm{~s}^{-1}$. The temperature ranged from 21 to $27^{\circ} \mathrm{C}$ during germination and from 21 to $24{ }^{\circ} \mathrm{C}$ during vegetative growth, with a RH between $60 \%$ and $80 \%$. Planting and nutritional management of the plants was carried out based on Ojodeagua et al. (2008).

Seeds, soil and germination trays were disinfected prior to sowing. The seeds were disinfected with $5 \%$ hypochlorite (W/V) for $3 \mathrm{~min}$ and with 70\% ethanol (w/v) for $1 \mathrm{~min}$, followed by six washes in sterile distilled water. The soil was disinfected with steam at an initial temperature of $100{ }^{\circ} \mathrm{C}$ and then maintained at $82^{\circ} \mathrm{C}$ for $30 \mathrm{~min}$. The germination trays were disinfected with $10 \%$ hypochlorite (w/v). 
Plant inoculation. Plants were inoculated twice: at emergency stage and $15 \mathrm{~d}$ after emergency. Bacterial concentration for each strain was standardized at $10^{7} \mathrm{CFU} \mathrm{mL}^{-1}$ in $1.0 \%$ sucrose (v/v) determined through absorbance $(\lambda=600 \mathrm{~nm})$. For inoculation, $1 \mathrm{~mL}$ standardized bacterial suspension was placed aseptically in the root zone of each plant.

Plant growth promotion. At day 35 after planting, plants were removed from the soil and their roots carefully washed. The length $(\mathrm{cm})$ and fresh and dry weight $(\mathrm{g})$ of both roots and aerial shoots were evaluated. Dry weight was determined after roots and shoots were dried in a stove until reaching constant weight $\left(70{ }^{\circ} \mathrm{C} / 48 \mathrm{~h}\right)$.

NPK determination in plant tissue and soil. NPK were determined through soil analysis methods of the Commission for Standardization and Accreditation of the Chilean Society of Soil Science. In plant the $\mathrm{N}$ analysis was carried out by the digestion method and colorimetric determination; in soil inorganic $\mathrm{N}$ was determined by colorimetry, nitrates via nitration of salicylic acid, and ammonium using Nessler reagent. Phosphorous content was determined by calcination and colorimetric determination of the phospho-vanadomolybdate, and $\mathrm{K}$ content was determined through calcination and atomic emission spectrometry.

\section{Statistical analysis}

Data obtained in laboratory were subjected to cluster analysis (standardized data) using Euclidean metric as a measure of distance. The defined clusters and the bacterial isolates of the best cluster(s) were subjected to a nonparametric variance analysis with the Kruskal Wallis test and a comparison of means test. Data obtained each trial in plant, completely randomized design with three replicates, were subjected to ANOVA and means were compared through the Tukey test. Analysis were realized with a probability of $\mathrm{p} \leq 0.05$ using the InfoStat/E 2013 software.

\section{RESULTS AND DISCUSSION}

\section{Selected rhizobacteria for $\mathbf{N}_{2}$ fixation, solubilization of $P$ and $K$}

$\mathbf{N}_{2}$ fixation and amonium production $\left(\mathbf{N}-\mathbf{N H}_{4}{ }^{+}\right)$. The 15 isolates evaluated had growth of bacterial colony in Burk's agar medium; 8 isolates had abundant growth, 4 had good growth and 3 had moderate growth. Determination of $\mathrm{N}-\mathrm{NH}_{4}{ }^{+}$in Burk's liquid medium showed that 12 out of the 15 strains made $\mathrm{NH}_{4}{ }^{+}$available (Table 1). These bacterial strains probably fixed the $\mathrm{N}_{2}$ contained in the air of the falcon tubes and used it for their metabolism. $\mathrm{N}_{2}$ fixation occurs when molecular $\mathrm{N}\left(\mathrm{N}_{2}\right)$ is converted into ammonia $\left.\left(\mathrm{NH}_{3}\right)^{-}\right)$by the enzyme complex nitrogenase, which consists of two metalloproteins, the molybdenum-iron protein (Protein 1) and the iron-protein (Protein 2). Nitrogenase requires the collaboration of two other proteins: ferrodoxin and avodoxin, which act as electron donors and natural reducers of nitrogenase. The electrons are transported to the nitrogenase by ferrodoxin and reach the iron-protein. This activates the Mo-Fe-protein and the reduction of $\mathrm{N}_{2}$ occurs, being then fixed as an amino compound (Hoffman et al., 2014). The process of $\mathrm{N}_{2}$ fixation varies between different bacterial genera. Most of biological $\mathrm{N}$ fixation is carried out by the activity of molybdenum nitrogenase, which is found in all diazotrophs (Carvalho et al., 2014).

The concentrations of $\mathrm{N}^{-\mathrm{NH}_{4}}{ }^{+}$produced ranged from 0.2 to $1.7 \mathrm{mg} \mathrm{L}^{-1}$ (Table 1). Studies on asymbiotic $\mathrm{N}_{2}$ fixing bacteria (NFB) have reported higher levels of $\mathrm{NH}_{4}{ }^{+}$than the ones on this work, with concentrations of $5.17 \mathrm{mg} \mathrm{L}^{-1}$ by Azotobacter sp.; $3.65 \mathrm{mg} \mathrm{L}^{-1}$ by Azotobacter vinelandii DSM 2289; 16.63 to $6.89 \mathrm{mg} \mathrm{L}^{-1}$ by Azotobacter vinelandii (GMA6 and GMA9); $4.68 \mathrm{mg} \mathrm{L}^{-1}$ by Azospirillum spp.; $1.948 \mathrm{mg} \mathrm{L}^{-1}$ by Azospirillum brasilense DSM 1224; $10.34 \mathrm{mg} \mathrm{L}^{-1}$ by Brevibacillus formosus (GMA3); and $5.88 \mathrm{mg} \mathrm{L}^{-1}$ by Stenotrophomonas sp. (GMA1) (Hartono et al., 2016).

For the selection of NFB, the 15 strains were grouped into three clusters (CC = 0.96): CL1, CL2 and CL3 (Figure 1A) CL1 presented mean $\mathrm{NH}_{4}{ }^{+}$concentrations of $1.53 \mathrm{mg} \mathrm{L}^{-1}$, producing $1.42 \mathrm{mg} \mathrm{L}^{-1}$ more than CL2 $\left(0.11 \mathrm{mg} \mathrm{L}^{-1} \mathrm{NH}_{4}^{+}\right)$and $0.88 \mathrm{mg} \mathrm{L}^{-1}$ more than CL3 $\left(0.65 \mathrm{mg} \mathrm{L}^{-1} \mathrm{NH}_{4}^{+}\right.$) (ANOVA, $\mathrm{P}=0.002$ ). However, CL3 did not show significant differences with respect to CL1 and CL2 (Figure 1B). Therefore, an ANOVA was performed between CL1 and CL2 isolates: Aj-19b (1.35 mg L-1 $\left.\mathrm{NH}_{4}^{+}\right)$, Hb-142 (0.70 mg L $\left.\mathrm{NH}_{4}^{+}\right)$, Tmt1-107 (0.60 mg L-1 $\left.\mathrm{NH}_{4}^{+}\right)$, Tmt-16 $\left(0.70 \mathrm{mg} \mathrm{L}^{-1} \mathrm{NH}_{4}^{+}\right)$. As no differences were found in terms of $\mathrm{NH}_{4}{ }^{+}$production $(\mathrm{p}=0.40)$, all isolates were selected for the plant trials.

The four bacterial strains selected as NFB were isolated from the following crops: chili, Aj-19b; faba bean, Hb-142; tomato, Tmt1-107 and Tmt-16. Nitrogen-fixing bacteria have the ability to develop different types of root associations with different plant species (Carvalho et al., 2014). 
Figure 1. Phenogram of the cluster analysis of the 15 rhizobacteria, and comparison between clusters: (A) (B) $\mathrm{NH}_{4}{ }^{+}$ production; (C) (D) P solubilization; (E) (F) K solubilization.
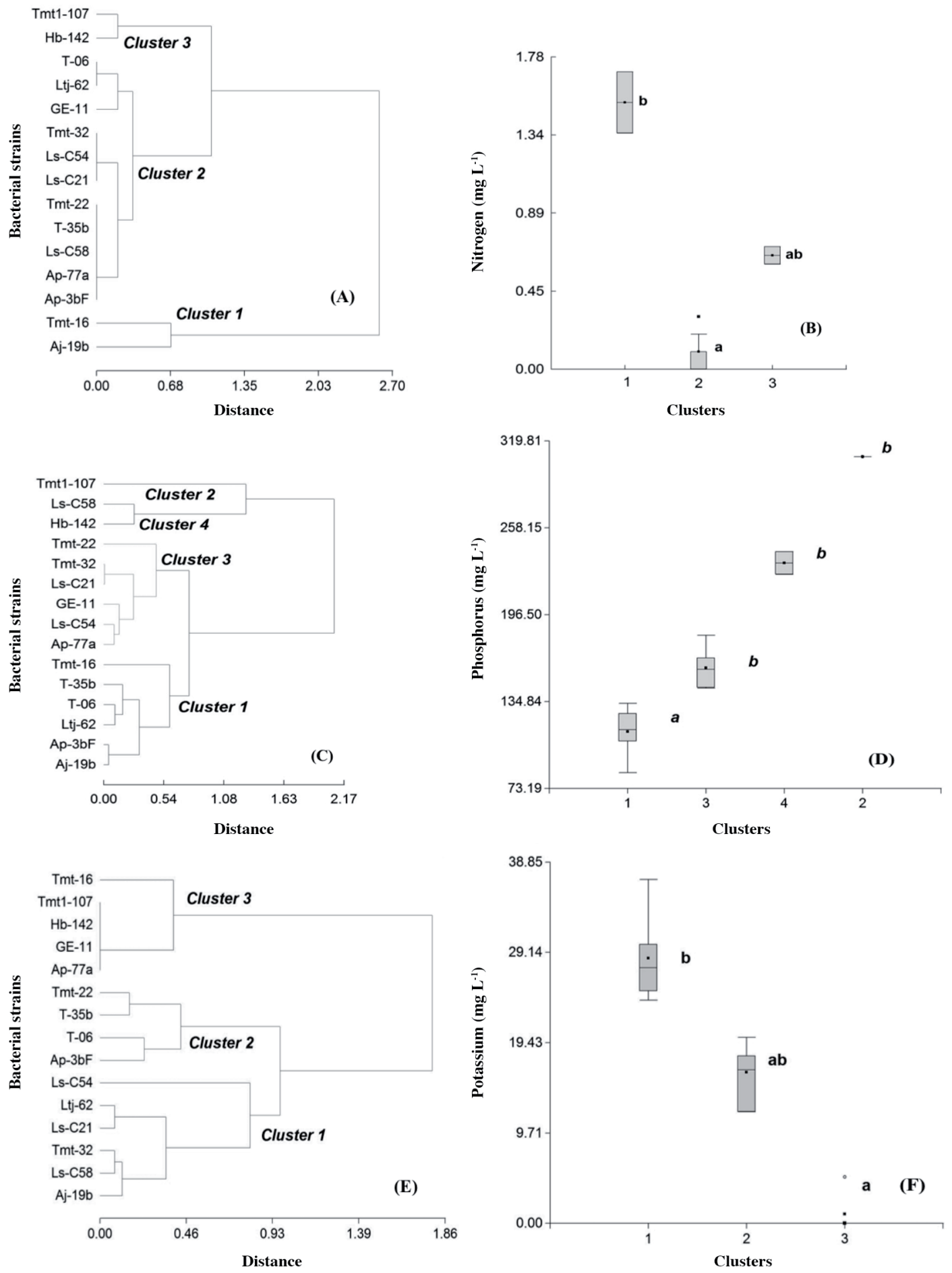

Average - average linkage, Euclidean distance. Means with the same letter are nonsignificantly different $(\mathrm{p}>0.05)$. 
Phosphate solubilization and $\mathbf{P}$ production $\left(\mathbf{P}-\mathbf{P O}_{4}\right)$. Out of 15 isolates evaluated, 12 bacterial isolates presenting solubilization halos on the PVK-agar plate, with a halo from 0.9 to $7.5 \mathrm{~mm}$ (Table 1). Solubilization of inorganic P from $\mathrm{Ca}_{3}\left(\mathrm{PO}_{4}\right)_{2}$ in PVK media occurs by secretion of organic and inorganic acids, such as citric, lactic, succinic and gluconic acids. Hydroxyl and carboxyl groups of acids chelate cations $\left(\mathrm{Ca}^{2+}\right)$ and lower the $\mathrm{pH}$ by releasing the phosphates (Behera et al., 2014).

Determination of the available $\mathrm{P}$ in solution showed that the 15 strains evaluated were able to solubilize the phosphate of the tricalcium phosphate $\mathrm{Ca}_{3}\left(\mathrm{PO}_{4}\right)_{2}$, ranging from 84.4 to $308.6 \mathrm{mg} \mathrm{L}^{-1}$. Several studies have reported that many isolates do not produce any visible halo zone on the agar plate, but they can solubilize several types of insoluble inorganic phosphate in liquid medium (Behera et al., 2017). This may be due to varying diffusion rates of different organic acids secreted by different microorganisms.

The 15 bacterial isolates were grouped into four clusters (CC =0.83); CL1, CL, CL3 and CL4 (Figure 1C), consisting of 6, 1, 6 and 2 isolates with average $P$ values of $113.45,308.60,158.70,233.15 \mathrm{mg} \mathrm{L}^{-1}$, respectively. ANOVA showed significant differences $(\mathrm{P}=0.0177)$ between CLs. The $\mathrm{CL} 1$ recorded the lowest $\mathrm{P}$ production in comparison with CL3, CL4 and CL2 (Figure 1D).

For the plant trials, the following isolates of CL2 and CL4 were selected: Tmt1-107 (308.60 mg P-PO $\mathrm{L}^{-1}$ ), Ls-C58 (241.20 mg P-PO $\left.\mathrm{L}^{-1}\right)$ and $\mathrm{Hb}-142\left(225.10 \mathrm{mg} \mathrm{P}-\mathrm{PO}_{4} \mathrm{~L}^{-1}\right)$. These isolates solubilized $\mathrm{P}$ in larger amounts than those reported in other studies by Ehsan et al. (2016) that determined P solubilization from tricalcium phosphate by species of the genus Pseudomonas, P. beteli and P. lini, which solubilized phosphate in a range from 18.30 to $147.53 \mu \mathrm{g} \mathrm{mL}^{-1}$. There are reports that indicate that the use of PSB in co-composting of urban waste $(95 \%)+$ phosphate rock (5\%) can generate up to $25 \mathrm{~kg} \mathrm{Pt}^{-1}$ fresh weight ha-1 (Naher et al., 2018).

Potassium solubilization and production. Out of 15 isolates evaluated 14 bacterial isolates solubilized K from K-feldspar in MAMs-agar, with a solubilization halo from 1.1 to $5.6 \mathrm{~mm}$ (Table 1). Solubilization of K occurs by secretion several types of organic acids; succinic, citric, gluconic, $\alpha$-ketogluconic and oxalic, and inorganic; acetate, citrate, oxalate that when released to the rhizosphere cause the fixed $\mathrm{K}$ of the minerals to be released and dissolved by processes of acidolysis, chelation and complexolysis. Figure 2 shows the effect of a bacterium on $\mathrm{K}$ mica (K-feldspar) by breaking down the mineral and resulting in a 5\% solubilization of the K contained in the feldspar. These KSB can produce several types of

Figure 2. Microphotographs of feldspar-K solubilization in MAMs media from plates with and without bacterial inoculum.
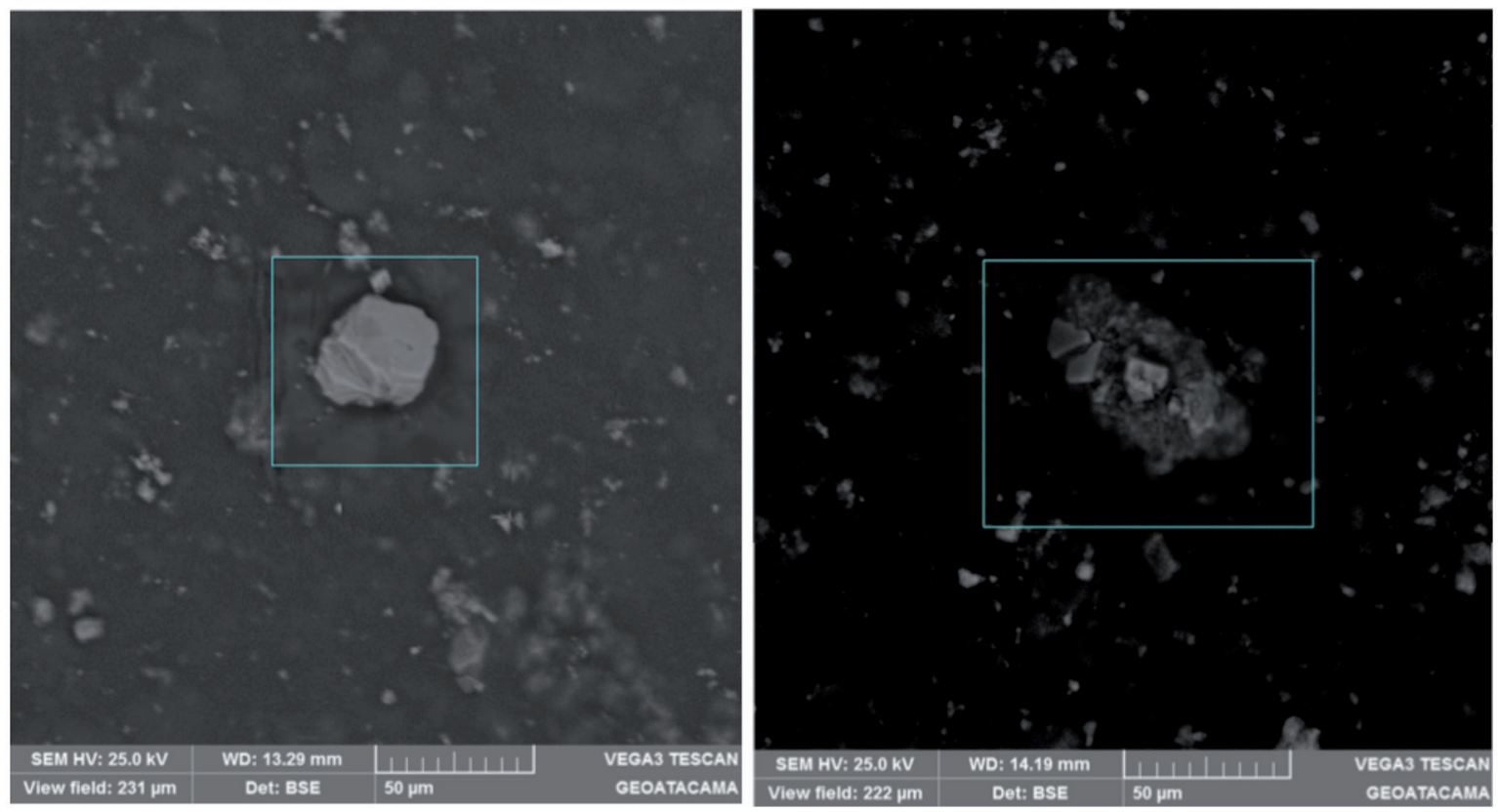

Unaltered K-feldspar, 14\% K (left) compared to K-feldspar inoculated with illite/muscovite reaction boundary, $9 \% \mathrm{~K}$, in modified Aleksandrov medium (MAMs) agar (right). 
organic acids that possibly break down the structure of the micas to satisfy their $\mathrm{Si}^{4+}$ and $\mathrm{K}^{+}$requirements in the culture medium within the plate, consequently reducing the $\mathrm{pH}$ of the medium.

Based on a CC $=0.82$ in the cluster analysis of the 15 bacterial isolates, three clusters were identified, CL1, CL2 and CL3 (Figure 1E), consisting of 6, 4 and 5 isolates with average $\mathrm{K}$ values of $28.5,16.25$ and $1.0 \mathrm{mg} \mathrm{L}^{-1}$, respectively. ANOVA showed significant differences $(\mathrm{P}=0.0018)$ between CL1 and CL3; CL1 isolate showed the highest $\mathrm{K}$-solubilizing capacity (Figure 1F). For the plant trials, six CL1 isolates were selected: Ls-C54 (37.0 mg K L'-1), Ls-C21 (30.0 mg K L'-1), Ltj-62 (29.0 mg K L $\left.{ }^{-1}\right)$, Tmt-32 (26.0 mg K L $\left.{ }^{-1}\right)$, Ls-C58 (25.0 $\left.\mathrm{mg} \mathrm{K} \mathrm{L}^{-1}\right)$, and Aj-19b (24.0 mg K L-1).

The six selected isolates showed $\mathrm{K}$ production ranging from 24.0 to $37.0 \mathrm{mg} \mathrm{L}^{-1}$ (Table 1). Similar ranges were obtained by Parmar and Sindhu (2013) from 15 to $48 \mathrm{mg} \mathrm{L}^{-1}$, when quantifying the solubilization of $\mathrm{K}$ from mica powder by six bacterial strains. These values were lower than those reported for the strain Bacillus mucilaginosus, AS1.153 when solubilizing $\mathrm{K}$ in motmorillonite, kaolinite and $\mathrm{K}$-feldspar, with values ranging between 90 and $140 \mathrm{mg} \mathrm{K} \mathrm{L}^{-1}$. However, these values are higher than those obtained by Zhang and Kong (2014), where 17 isolates of KSB reached from 0.59 to $4.4 \mathrm{mg} \mathrm{K} \mathrm{L}^{-1}$, and by Pseudomonas azotoformans, which solubilized $6.03 \mathrm{mg} \mathrm{K} \mathrm{L}^{-1}$ (Saha et al., 2016). The solubilization of $\mathrm{K}$ varies with the nature of the minerals (motmorillonite, kaolinite, $\mathrm{K}$-feldspar, muscovite, biotite, illite, orthoclases) that contain $\mathrm{K}$ and aerobic conditions (Meena et al., 2015).

\section{Identification of the selected bacteria}

For all selected strains, a $1200 \mathrm{bp}$ fragment of the 16S rRNA gene was amplified. The phylogenetic tree based on 16S rRNA grouped the bacterial strains into three genera: Pseudomonas, Rahnella and Acinetobacter (Figure 3).

Of the strains within the Pseudomonas genus, Ltj-62 and Aj-19b were closely related to the type strain P.brassicacearum

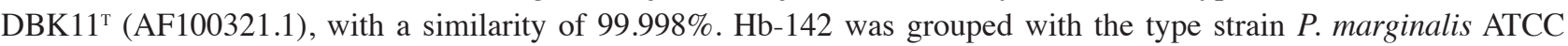
$10844^{\mathrm{T}}(\mathrm{AB} 021401.1)$, with a similarity of $100 \%$. Tmt- 16 was grouped with $P$. gessardi $^{\mathrm{T}}$ (AF074384.1), with a similarity of $99.971 \%$, and Tmt-32 and Ls-C21 were grouped with P. koreensis Ps 9-14 ${ }^{\mathrm{T}}=\mathrm{LMG} 21318^{\mathrm{T}}=\mathrm{KACC} 10848^{\mathrm{T}}(\mathrm{NR}$ 025228.1 ), with similarity scores of $99.998 \%$ and $100 \%$, respectively.

Bacteria of the Pseudomonas genus have been extensively described as PGPR, and endophytes of several plants (Carvalho et al., 2014). Species such as P. monteilii and P. mandelii have been reported as NFB associated with rice plants (Habibi et al., 2014). In fact, Pseudomonas is a widespread bacterial genus, which presents the highest $\mathrm{P}$ solubilizing activity in rhizosphere soil (Bahena et al., 2015). Pseudomonas azotoformans has also been reported as K solubilizing bacteria (Saha et al., 2016).

LsC-58 and Ls-C54 were identified as belonging to the Acinetobacter genus and were closely related to the type strain A. calcoaceticus DSM30006 ${ }^{\mathrm{T}}$ (X81661.1), with similarity scores of $99.989 \%$ and $100 \%$, respectively. Acinetobacter calcoaceticus has also been reported as PSB, and a Zn oxidizer (Rokhbakhsh-Zamin et al., 2011). Acinetobacter spp. has been described to have a high biological $\mathrm{N}$ fixation in sugarcane (Taulé et al., 2012). When associated with mycorrhizal fungi, this species has shown potential to contribute to remediating alkaline-saline soils contaminated with petroleum (Xun et al., 2015).

Tmt1-107 was identified as Rahnella sp., and as closely related to the type strain R. aquatilis 334T (X79936.1). Rahnella sp. is a bacterium described as PGPR in major agricultural crops. Rahnella aquatilis has been described as a PSB in the rhizosphere of Eucalyptus (Angulo et al., 2014). Furthermore, Rahnella sp., BIHB 783, has been described as an ammonia producing bacteria, and a P solubilizer, in barley, chickpea, pea, and maize (Vyas et al., 2010).

\section{Endophytic capacity of the selected bacteria}

Endophytic bacteria colonize any region within the epidermis of the plant root, and they can reside in apoplastic intercellular spaces and the xylem vessel apoplast. These bacteria establish in less competitive niches that present better conditions for $\mathrm{N}$ fixation and assimilation of fixed $\mathrm{N}$ by the plant (Carvalho et al., 2014). Of the plants inoculated in the pot trials, 30 different strains were isolated based on the physical appearance of each colony. However, when the genetic fingerprint of these isolates was determined, results did not coincide with the band patterns of the original strain. Therefore, none of the eight strains selected as NFB, PSB and KSB had the ability to act as endophytes (Figure 4). 
Figure 3. Neighbor joining phylogenetic tree based on 16S rRNA sequencing of phylogenetic tree of Pseudomonas spp., Rahnella spp. and Acinetobacter spp. Bootstrap values are indicated on branches only when higher than 70 . The type strains sequences in the phylogram were obtained from GenBank (accession number in parentheses). The bacterial strains studied are marked in bold.

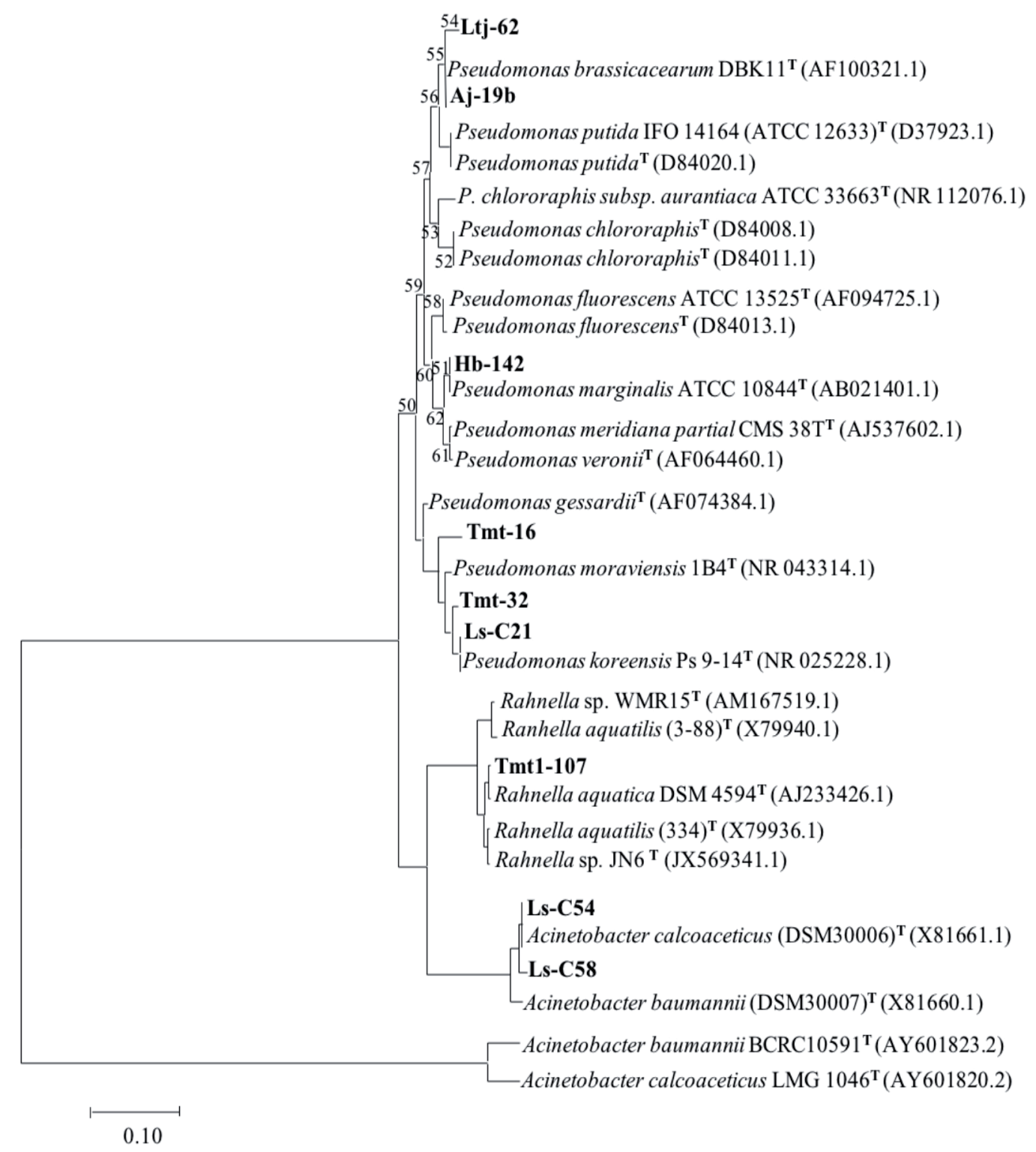

\section{Effect of the selected bacteria in plant and soil}

Effect of NFB. Tmt1-107 Rahnella aquatica, and Hb-142 P. marginalis did not generate a positive effect on tomato plant growth. On the other hand, Tmt-16, P. gessardi $(7.38 \mathrm{~cm})$, increased root growth in $23.57 \%$ compared to the negative control $(5.64 \mathrm{~cm})(\mathrm{p}=0.05)$. However, Tmt-16 was the strain that resulted in the lowest plant height, reaching $5.50 \mathrm{~cm}(\mathrm{p}$ $=0.0047)$, which was $2.17 \mathrm{~cm}$ lower than the control $(7.67 \mathrm{~cm})$. The results on higher root growth coincide with those of Naiman et al. (2009). The former reported an increase in root growth from $18 \%$ to $26 \%$ in tomato plants inoculated with Bacillus subtilis BEB-13bs (post-transplant) compared to the untreated control; the latter reported that there was a $40 \%$ increase in root biomass in wheat inoculated with P. fluorescens.

Tmt-16, P. gessardi, significantly increased $\mathrm{N}$ content in plant tissue in $2.60 \%$, compared to the control and to strains Tmt1-107, Hb-142 ( $\mathrm{p}=0.0013)$. This strain maintained the highest amount of $\mathrm{N}$ available in the soil, $2.95 \mathrm{mg} \mathrm{kg}^{-1}(\mathrm{p}$ $=0.0006)$, and a higher content of $\mathrm{N}^{-N_{4}}{ }^{+} 1.95 \mathrm{mg} \mathrm{kg}^{-1}(\mathrm{p}=0.0296)$ (Table 2). This indicates that Tmt-16, $P$. gessardi, 
Figure 4. PCR amplification of the bacterial isolates from leaf and stem of the plants inoculated.
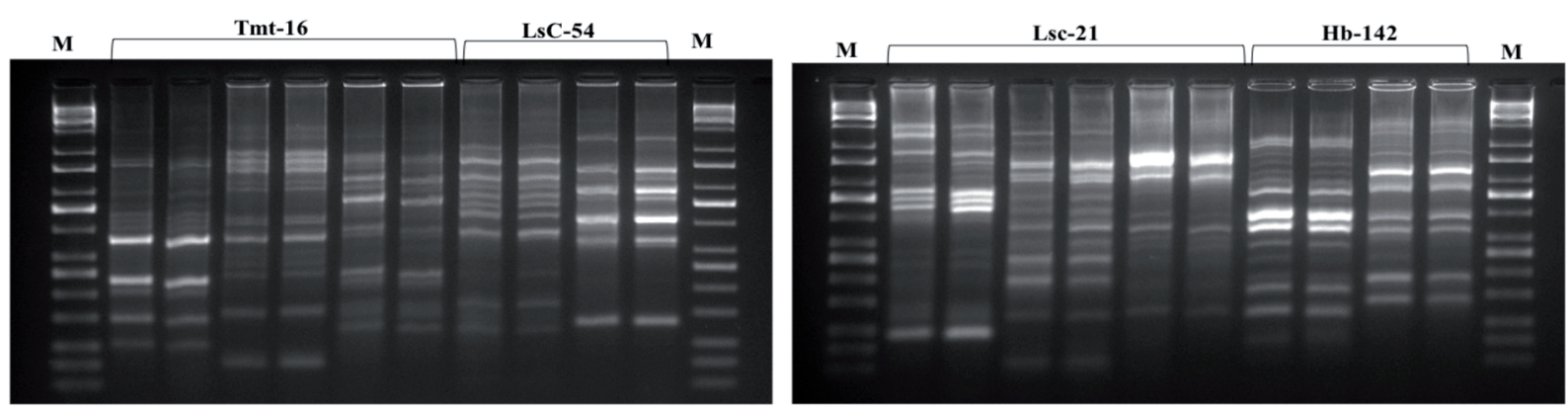

From left to right, Tmt-16; band 1 and 2, control-strain, band 3 and 4 isolated from the leaf, band 5 and 6 isolated from the stem. LsC-54; band 1 and 2 control-strain, band 3 and 4 isolated from the leaf. LsC-21; band 1 and 2 control-strain, band 3 and 4 isolated from the leaf, band 5 and 6 isolated from the stem.

Table 2. Effect of the $\mathrm{N}$-fixing bacteria on $\mathrm{N}$ content in plant and $\mathrm{N}$ availability in soil.

\begin{tabular}{lcccc}
\hline Isolates & $\mathrm{N}$ uptake & $\mathrm{N}$ available in soil & $\mathrm{N}-\mathrm{NH}_{4}{ }^{+}$in soil & $\mathrm{N}^{-\mathrm{NO}_{3}}$ in soil \\
\cline { 3 - 3 } & $\%$ & $\mathrm{mg} \mathrm{kg}^{-1}$ & \\
Tmt-16 & $2.60 \mathrm{a}$ & $2.95 \mathrm{a}$ & $1.95 \mathrm{a}$ & 1.00 \\
Tmt1-107 & $1.19 \mathrm{c}$ & $1.80 \mathrm{~b}$ & $1.25 \mathrm{~b}$ & 0.55 \\
$\mathrm{Hb}-142$ & $1.25 \mathrm{c}$ & $1.70 \mathrm{~b}$ & $0.90 \mathrm{~b}$ & 0.90 \\
Control & $1.73 \mathrm{~b}$ & $1.50 \mathrm{~b}$ & $0.95 \mathrm{~b}$ & 0.55 \\
\hline
\end{tabular}

Mean values with the same letter are nonsignificantly different $(\mathrm{p}>0.05)$.

is an $\mathrm{N}$-fixing bacteria with potential use as biofertilizer or growth promoter. The change in root growth by Tmt-16, $P$. gessardi, resulted in greater root surface area for the uptake of nutrients and production, which also explains the higher $\mathrm{N}$ concentration in plant tissue. Studies in tomato indicate that inoculation with Bacillus amyloliquefaciens IN937a and B. pumilus $\mathrm{T} 4$ may increase plant growth and $\mathrm{N}$ availability. However, the effect of bacteria can vary and is influenced by factors such as $\mathrm{N}$ source, $\mathrm{N}$ rate, and soil fertility (Fan et al., 2017). In 2005, studies with the tomato 'Amalia' showed that applications of Azospirillum sp. (AzoFert) combined with $120 \mathrm{~kg} \mathrm{~N}$ increased yield in $11 \%$ in comparison to the control, resulting in a reduction of $30 \mathrm{~kg} \mathrm{~N} \mathrm{ha}^{-1}$ in the crop, which represented a decrease of $20 \% \mathrm{~N}$ application (Alfonso et al., 2005).

In cereals, the estimates of biological $\mathrm{N}_{2}$ fixation by free-living bacteria generally range between 5 and $50 \mathrm{~kg} \mathrm{~N} \mathrm{ha}^{-1} \mathrm{yr}^{-1}$ in enriched soil environments and plant residues (Roper and Gupta, 2016). The process of $\mathrm{N}_{2}$ fixation varies between different bacterial genera. Most of biological $\mathrm{N}$ fixation is carried out by the activity of molybdenum nitrogenase, which is found in all diazotrophs (Carvalho et al., 2014). Of the large number of free-living $\mathrm{N}_{2}$-fixing bacteria, the following genera have shown potential as biofertilizers or growth promoters: Azospirillum, Azotobacter, Beijerinckia, Derxia, Pseudomonas, Herbaspirillum, Burkholderia, Gluconacetobacter, Derxia, Beijerinckia and Azotobacter, Enterobacter, Bacillus, Alcaligenes, Klebsiella, Lysobacter sp. and Paenibacillus polymyxa (Majeed et al., 2018). Of all these genera, only the genus Pseudomonas was identified in this study.

Effect of PSB. Hb-142 P. marginalis, LsC-58 A. calcoaceticus and Tmt1-107 R. aquatilis did not generate a positive effect on tomato plant growth. Regarding P solubilization, these strains did not generate an increase in the initial content of available $\mathrm{P}$ in the soil $(19.2 \mathrm{mg} \mathrm{kg}-1)$. On the contrary, available $\mathrm{P}$ diminished, ranging from 14.8 to $16.8 \mathrm{mg} \mathrm{kg}^{-1}$. $\mathrm{P}$ content in the plant tissue ranged between $0.13 \%$ and $0.14 \%$ and was similar to that of the plants without bacterial inoculum $(0.14 \%)$.

The effectiveness of PSB depends on the ability of the isolates to colonize the rhizosphere and maintain their biological activity, and on the types of metabolites produced and their release rate (Zhu et al., 2011). The performance of the PSB is influenced by with the nutritional richness and soil physicochemical properties such as organic matter, temperature and 
soil pH (Alori et al., 2017). The results obtained indicate that the effect of the bacteria on plants and soil was strongly influenced by the soil $\mathrm{pH}$ (5.66). This is due to the fact that tomatoes grow best in slightly acid soil with a pH range from 6.0 to 7.5, and for the best replenishment of $\mathrm{P}$ in the soil, the $\mathrm{pH}$ should be in the range of 6 to 7 . Therefore, the increase in soil acidity from 5.66 to 5.3 at the end of the experiment probably resulted in the formation of aluminum and iron phosphates, which led to symptoms of P deficiency in plants. On the other hand, most solubilizing microorganisms can solubilize calcium phosphate complexes and only some can solubilize aluminum or iron phosphate. Therefore, further studies are required to evaluate these PSB, which were selected in laboratory, in another type of soil and/or with slightly acid $\mathrm{pH}$ ranges.

Effect of KSB. The five bacterial strains classified as KSB neither promoted growth in tomato plants nor increased K content. The K solubilizing strains Ls-C21 P. koreensis, Ltj- 62 P. brassicacearum and LsC-58 A. calcoaceticus reached 17.0 to $19.0 \mathrm{mg} \mathrm{kg}^{-1}$ available $\mathrm{K}(\mathrm{p}=0.0002)$ and 0.04 to $0.05 \mathrm{mg} \mathrm{kg}^{-1}$ exchangeable $\mathrm{K}$ ( $\mathrm{p}=0.0023$ ). Ls-C21, had the highest amount of available $\mathrm{K} 19.00 \mathrm{mg} \mathrm{kg}^{-1}$, maintaining $6 \mathrm{mg} \mathrm{kg}^{-1}$ more than the soil without bacterial inoculation (Figure 5A, B). Sirajuddin et al. (2016) found that B. pumilus increases the solubility of $\mathrm{K}^{+}$and the antioxidant activity induced by tomato plants, which helps plants maintain their yields under stress conditions. About $90 \%$ of $\mathrm{K}$ exists in forms of insoluble rock and silicate minerals, but soluble $\mathrm{K}$ is generally very low in the soil (Parmar and Sindhu, 2013). In fact, $\mathrm{K}$ deficiency has become a major limitation for crop production. Inadequate $\mathrm{K}$ nutrition negatively affects root development, seed production and yield (Zhang and Kong, 2014). These results indicate that these three strains have potential as K solubilizers and can be an alternative to maintain $\mathrm{K}$ levels in the soil.

Figure 5. Effect of K solubilizing bacteria on the soil: Available (A) and exchangeable K (B).
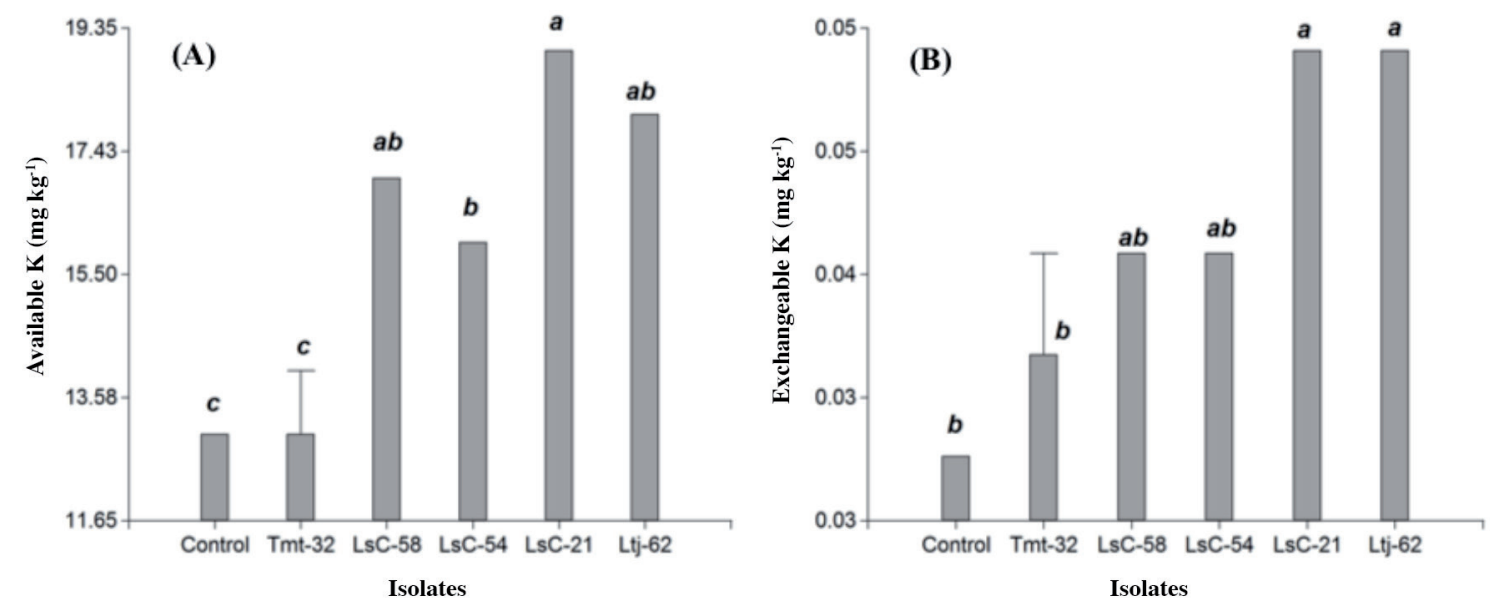

Means with the same letter are nonsignificantly different $(\mathrm{p}>0.05)$.

\section{CONCLUSIONS}

Four bacteria strains were selected for their capacity to fix $\mathrm{N}_{2}$, three for their ability to solubilize $\mathrm{P}$, and six for their capacity to solubilize biotite and K-feldspar, isolated from tomato, lentil, chili pepper, faba bean and lettuce crops in Andisol and Alfisol soils.

These bacteria selected in laboratory, four bacteria were selected because of their capacity to maintain levels of $\mathrm{N}$ and $\mathrm{K}$ available to plants, in an Ultisol with a low content of available $\mathrm{N}$ and $\mathrm{K}$. Three of them belong to the genus Pseudomonas: Tmt-16, P. gessardi; Ls-C21, P. koreensis; Ltj-62 P. brassicacearum and one corresponds to genus Acinetobacter: LsC58 , A. calcoaceticus, collected from an Ultisol and Andisol from tomato, lettuce and lentil crops. Tmt-16 increased root growth, which is a quality parameter in the production of tomato seedlings. P solubilizing strains did not show a positive effect on tomato plant growth or increase in available soil $\mathrm{P}$. 
These four endemic rhizobacteria of Chile can be potentially used as biofertilizers, allowing a reduction in the use of chemical fertilizers and a more sustainable production of tomatoes.

\section{REFERENCES}

Alfonso, E.T., Leyva, A., y Hernández, A. 2005. Microorganismos benéficos como biofertilizantes eficientes para el cultivo del tomate (Lycopersicon esculentum Mill). Revista Colombiana de Biotecnología 8(2):47-54.

Alori, E.T., Glick, B.R, and Babalola, O.O. 2017. Microbial phosphorus solubilization and its potential for use in sustainable agriculture. Frontiers in Microbiology 8:971. doi:10.3389/fmicb.2017.00971.

Angulo, V., Sanfuentes, E.A., Rodríguez, F., y Sossa, K. 2014. Caracterización de rizobacterias promotoras de crecimiento en plántulas de Eucalyptus nitens. Revista Argentina de Microbiología 46(4):338-347. doi:10.1016/S0325-7541(14)70093-8.

Bahena, M.H.R., Salazar, S., Velázquez, E., Laguerre G., and Peix, A. 2015. Characterization of phosphate solubilizing rhizobacteria associated with pea (Pisum sativum L.) isolated from two agricultural soils. Symbiosis 67:33. doi:10.1007/s13199-015-0375-6.

Behera, B., Parida, S., Dutta, S., and Thatoi, H. 2014. Isolation and identification of cellulose degrading bacteria from mangrove soil of Mahanadi river delta and their cellulase production ability. American Journal of Microbiological Research 2(1):41-46. doi:10.12691/ajmr-2-1-6.

Behera, B.C., Yadav, H., Singh, S.K., Mishra, R.R., Sethi, B.K., Dutta, S.K., et al. 2017. Phosphate solubilization and acid phosphatase activity of Serratia sp. isolated from mangrove soil of Mahanadi river delta, Odisha, India. Journal of Genetic Engineering and Biotechnology 15(1):169-178. doi:10.1016/j.jgeb.2017.01.003.

Carvalho, T.L., Balsemão-Pires, E., Saraiva, R.M., Ferreira, P.C., and Hemerly, A.S. 2014. Nitrogen signalling in plant interactions with associative and endophytic diazotrophic bacteria. Journal of Experimental Botany 65(19):5631-5642. doi:10.1093/jxb/eru319.

Cedeño-García, G.A., Gerding, M., Moraga, G., Inostroza, L., Fisher, S., Sepúlveda-Caamaño, M., et al. 2018. Plant growth promoting rhizobacteria with ACC deaminase activity isolated from Mediterranean dryland areas in Chile: Effects on early nodulation in alfalfa. Chilean Journal of Agricultural Research 78:360-369. doi:10.4067/S0718-58392018000300360.

Ehsan, M., Ahmed, I., Hayat, R., Iqbal, M., Bibi, N., and Khalid, N. 2016. Molecular identification and characterization of hosphate solubilizing Pseudomonas sp. isolated from rhizosphere of mash bean (Vigna mungo L.) for growth promotion in wheat. Journal of Agricultural Science and Technology 18:775-788.

Fan, X.H., Zhang, S.A., Mo, X.D., Li, Y.C., Fu, Y.Q., and Liu, Z.G. 2017. Effects of plant growth-promoting rhizobacteria and $\mathrm{N}$ source on plant growth and $\mathrm{N}$ and $\mathrm{P}$ uptake by tomato grown on calcareous soils. Pedosphere 27(6):1027-1036. doi:10.1016/S1002-0160(17)60379-5.

Gerding, M., Oyarzúa,P., García, L., Fischer, S., Norambuena,C., Barahona, V., et al. 2017. Diversity and symbiotic effectiveness of Adesmia spp. root nodule bacteria in central and southern Chile. Symbiosis 72:61-72. doi:10.1007/s13199-016-0440-9.

Guiñazú, L., Andrés, J., Rovera, M., Balzarini, M., and Rosas, S. 2013. Evaluation of rhizobacterial isolates from Argentina, Uruguay and Chile for plant growth-promoting characteristics and antagonistic activity towards Rhizoctonia sp. and Macrophomina sp. in vitro. European Journal of Soil Biology 54:69-77. doi:10.1016/j.ejsobi.2012.09.007.

Habibi, S., Djedidi, S., Prongjunthuek, K., Mortuza, M.F., Ohkama-Ohtsu, N., and Sekimoto, H. 2014. Physiological and genetic characterization of rice nitrogen fixer PGPR isolated from rhizosphere soils of different crops. Plant and Soil 379:51-66. doi:10.1007/s11104-014-2035-7.

Hariprasad, P., and Niranjana, S.R. 2009. Isolation and characterization of phosphate solubilizing rhizobacteria to improve plant health of tomato. Plant and Soil 316:13-24. doi:10.1007/s11104-008-9754-6.

Hartono, H., Nurfitriani, Asnawati, F., Citra, H., Handayani, N.I., Junda, M., et al. 2016. Ability of ammonium excretion, indol acetic acid production, and phosphate solubilization of nitrogen-fixing bacteria isolated from crop rhizosphere and their effect on plant growth. ARPN Journal of Engineering and Applied Sciences 11(19):11735-11741.

Hoffman, B.M.,Lukoyanov, D., Yang, Z., Y., Dean, D.R., and Seefeldt, L.C. 2014. Mechanism of nitrogen fixation by nitrogenase: The next stage. Chemical Reviews 114(8):4041-4062. doi:10.1021/cr400641x.

Majeed, A., Muhammad, Z., and Ahmad, H. 2018. Plant growth promoting bacteria: role in soil improvement, abiotic and biotic stress management of crops. Plant Cell Reports 37:1599-1609. doi:10.1007/s00299-018-2341-2.

Meena, V.S., Maurya, B.R., and Verma, J.P. 2014. Does a rhizospheric microorganism enhance $\mathrm{K}^{+}$availability in agricultural soils? Microbiological Research 169:337-347. doi:10.1016/j.micres.2013.09.003.

Meena, V.S., Maurya, B.R., Verma, J.P., Aeron, A., Kumar, A., Kim, K., et al. 2015. Potassium solubilizing rhizobacteria (KSR): Isolation, identification, and K-release dynamics from waste mica. Ecological Engineering 81:340-347. doi:10.1016/j.ecoleng.2015.04.065.

Naher, U.A., Sarkar, M.I.U., Jahan, A., and Biswas J.C. 2018. Co-Composting urban waste, plant residues, and rock phosphate: biochemical characterization and evaluation of compost maturity. Communications in Soil Science and Plant Analysis 49(6):751-762. doi:10.1080/00103624.2018.1435799. 
Naiman, D.A., Latrónico, A., and Salamone, G.I.E. 2009. Inoculation of wheat with Azospirillum brasilense and Pseudomonas fluorescens: Impact on the production and culturable rhizosphere microflora. European Journal of Soil Biology 45(1):44-51. doi:10.1016/j.ejsobi.2008.11.001.

Ojodeagua, A.J., Castellanos, R.J.Z., Muñoz, R.J.J., Alcántar, G.G., Tijerina, C.T., Vargas, T.P., et al. 2008. Eficiencia de suelo y tezontle en sistemas de producción de tomate en invernadero. Revista Fitotecnia Mexicana 31(4):367-374.

Parmar, P., and Sindhu, S.S. 2013. Potassium solubilization by rhizosphere bacteria: influence of nutritional and environmental conditions. Journal of Microbiology Research 3(1):25-31. doi:10.5923/j.microbiology.20130301.04.

Parsa, S., Ortiz, V., and Vega, F. 2013. Establishing fungal entomopathogens as endophytes: towards endophytic biological control. Journal of Visualized Experiment 74:50360. doi:10.3791/50360.

Rokhbakhsh-Zamin, F., Sachdev, D., Kazemi-Pour, N., Engineer, A., Pardesi, K.R., Zinjarde, S., et al. 2011. Characterization of plant-growth-promoting traits of Acinetobacter species isolated from rhizosphere of Pennisetum glaucum. Journal of Microbiology and Biotechnology 21:556-566. doi:10.4014/jmb.1012.12006.

Roper, M.M., and Gupta, V.S.R. 2016. Enhancing non-symbiotic $\mathrm{N}_{2}$ fixation in agriculture. Open Agriculture Journal 10:7-27. doi:10.2174/1874331501610010007.

Saha, M., Maurya, B.R., Meena, V.S., Bahadur, I., and Kumar. A. 2016. Identification and characterization of potassium solubilizing bacteria (KSB) from Indo-Gangetic Plains of India. Biocatalysis and Agricultural Biotechnology 7:202-209. doi:10.1016/j.bcab.2016.06.007.

Sepúlveda-Caamaño, M., Gerding, M., Vargas, M., Moya-Elizondo, E., Oyarzúa, P., and Campos, J. 2018. Lentil (Lens culinaris L.) growth promoting rhizobacteria and their effect on nodulation in coinoculation with rhizobia. Archives of Agronomy and Soil Science 64(2):244-256. doi:10.1080/03650340.2017.1342034.

Sirajuddin, X., Khan, A., Ali, L., Chaudhary, H.J., Munis, M.F.H., Bano, A., et al. 2016. Bacillus pumilus alleviates boron toxicity in tomato (Lycopersicum esculentum L.) due to enhanced antioxidant enzymatic activity. Scientia Horticulturae 200:178-185. doi:10.1016\%2Fj.scienta.2016.01.024.

Tamura, K., Nei, M., and Kumar, S. 2004. Prospects for inferring very large phylogenies by using the neighbor-joining method. Proceedings of the National Academy of Sciences of the United States of America 101:11030-11035. doi:10.1073/pnas.0404206101.

Taulé, C., Mareque, C., Barlocco, C., Hackembruch, F., Reis, V.M., Sicardi, M., et al. 2012. The contribution of nitrogen fixation to sugarcane (Saccharum officinarum L.), and the identification and characterization of part of the associated diazotrophic bacterial community. Plant and Soil 356:35-49. doi:10.1007/s11104-011-1023-4.

Vyas, P., Robin, J., Sharma, K.C., Rahi, P., Gulati, A., and Gulati, A. 2010. Cold-adapted and rhizosphere-competent strain of Rahnella sp. with broad-spectrum plant growth-promotion potential. Journal of Microbiology and Biotechnology 20 (12):1724-1734. doi:10.4014/jmb.1007.07030.

Xun, F., Xie, B., Liu, S., and Guo, Ch. 2015. Effect of plant growth-promoting bacteria (PGPR) and arbuscular mycorrhizal fungi (AMF) inoculation on oats in saline-alkali soil contaminated by petroleum to enhance phytoremediation. Environmental Science and Pollution Research 22(1):598-608. doi:10.1007/s11356-014-3396-4.

Zhang, F., and Kong, F. 2014. Isolation and identification of potassium-solubilizing bacteria from tobacco rhizospheric soil and their effect on tobacco plants. Applied Soil Ecology 82:18-25. doi:10.1016/j.apsoil.2014.05.002.

Zhu, F., Qu, L., Hong, X., and Sun, X. 2011. Isolation and characterization of a phosphate solubilizing halophilic bacterium Kushneria sp. YCWA18 from Daqiao Saltern on the coast of Yellow Sea of China. Evidence-Based Complementary and Alternative Medicine 2011:1-6. doi:10.1155/2011/615032. 